SASBE

$7,3 / 4$

Received 11 August 2017 Revised 13 November 2017 20 April 2018

Accepted 2 May 2018

\section{Operating energy demand of various residential building typologies in different European climates}

\author{
Brian Cody, Wolfgang Loeschnig and Alexander Eberl \\ Institute of Buildings and Energy, Technische Universitat Graz, Graz, Austria
}

\begin{abstract}
Purpose - The work described below compares three very different residential typologies in terms of their energy performance in operation. The purpose of this paper is to identify the influence of building typologies and corresponding urban morphologies on operational energy demand and the potential for building integrated energy production.

Design/methodology/approach - Two of the typologies studied are apartment buildings while the third comprises single-family homes located on small plots. An important factor under consideration is the insertion into the respective urban design configuration so that mutual shading of the buildings and the ensuing impact on energy performance is evaluated. Heating and cooling demands, as well as the potential for building-integrated electricity production were investigated for four different European climates in a dynamic thermal simulation environment.

Findings - The results show that the investigated apartment buildings have a lower operational energy demand than the single-family home in all climates. This advantage is most pronounced in cool climate conditions. At the same time the investigated single-family home has the highest potential for building integrated renewable energy production in all climates. This advantage is most pronounced in low latitudes. Originality/value - The study builds up on generic buildings that are based on a common urban grid and are easily comparable and scalable into whole city districts. Still, these buildings are planned into such detail, that they provide fully functional floor plans and comply with national building regulations. This approach allows us to draw conclusions on the scale of individual buildings and at an urban scale at the same time.

Keywords Renewable energy, Building simulation, Building typologies, Operational energy,
\end{abstract} Residential buildings, Urban fabric

Paper type Research paper

\section{Introduction}

The work presented here is part of a larger research project (Cody and Loeschnig 2011; Loeschnig 2012), which aims to gain a deeper understanding of the role of urban density in the energy efficiency and sustainability of cities. The central aim of the project is to study the relationship between urban density and energy performance of a city or urban area and determine, if possible, the optimal degree of urban density in a certain context. It is proposed, that there is an optimal degree of urban density in terms of the overall energy demand of a city or urban area, when the total energy demand for buildings and transportation is considered and the potential for building integrated renewable energy production is also taken into account.

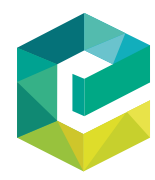

(C) Brian Cody, Wolfgang Loeschnig and Alexander Eberl. Published by Emerald Publishing Limited. This article is published under the Creative Commons Attribution (CC BY 4.0) licence. Anyone may reproduce, distribute, translate and create derivative works of this article (for both commercial and non-commercial purposes), subject to full attribution to the original publication and authors. The full terms of this licence may be seen at http://creativecommons.org/licences/by/4.0/legalcode

The authors approve that this research did not receive any funding and was not driven by any financial or business interests. The research was conducted within the framework of basic research at the Institute of Buildings and Energy without the involvement of external partners. There is no potential conflict of interest.
Smart and Sustainable Built Environment Vol. 7 No. $3 / 4,226-250$
pp. $22-$ Powish 2046-6099 DOI 10.1108/SASBE-08-2017-0035 Emerald Publishing Limited 
It is to be expected, that the specific energy demand per person due to transportation reduces with increasing urban density, as the land area required for a given population decreases and therefore the expected overall travel distance should also become less with increasing density. Higher densities also make public transportation systems more viable.

Earlier studies provide some evidence for this relationship between higher urban density and reduced specific energy demand for transportation (Brownstone and Golob, 2009; Ewing and Cervero, 2010; Nichols and Kockelman, 2014). Increasing urban density can also lead to reduced building energy demand, if apartment buildings instead of single-family dwellings are employed (Newton et al., 2000; Norman et al., 2006; Stejskal et al., 2011).

Previous research at the Institute of Buildings and Energy suggested, that city models with low energy consumption use more land than other models, which have higher energy demand, when the entire energy demand is met by renewable energy sources and the land required to achieve this is included in the land area for the city (see Figure 1, Loeschnig, 2012, p. 149). Therefore ultimately a decision will have to be made between city models with the lowest energy use and city models with the lowest land use.

Notwithstanding the obvious advantages of mixed use urban areas, based on the fact that 60-70 per cent of all building floor space in a country like Austria is dedicated to housing (Statistics Austria, 2009) and therefore large areas in our cities remain predominantly monofunctional residential areas, this part of the research project thus comprised the evaluation of the energy performance of various residential building typologies.

\section{Literature review}

Studies on urban fabric and energy demand

Compagnon (2004) investigated solar and daylight availability in the urban fabric and found that solar and daylight availability on facades can be significantly improved by changes in the layout and orientation of buildings at a constant building density (pp. 325-327).

Steemers (2003) suggested that relatively high residential densities can be achieved in the UK without a significant impact on space heating requirements if average obstruction angles stay below about $30^{\circ}$. This would allow a theoretical FAR of up to 2.5 without

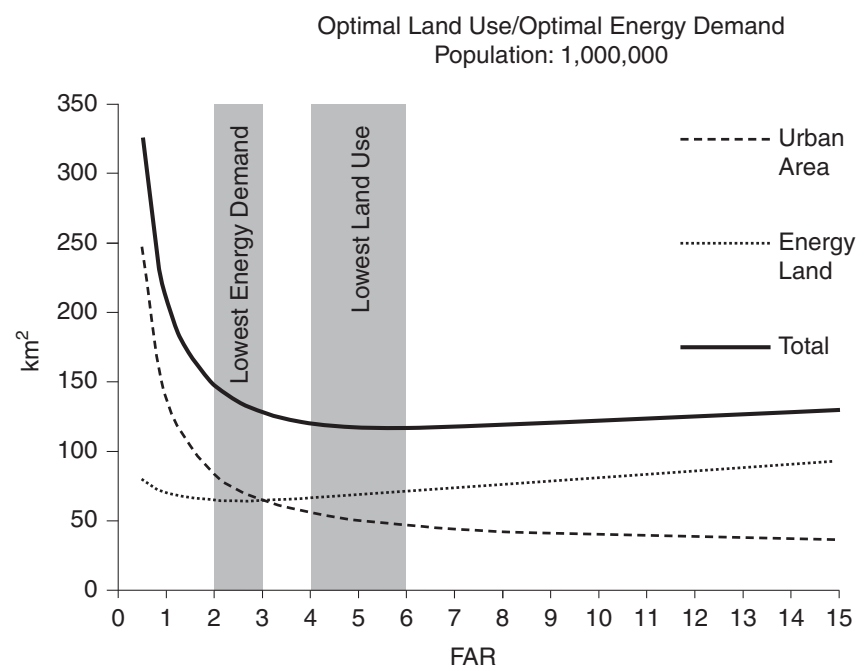

Source: Loeschnig 2012, p. 149

Figure 1. Optimal energy use versus optimal land use
Residential building typologies

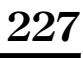


SASBE $7,3 / 4$ negative impact on operational energy demand (p. 6). However the study focussed on office buildings and did not provide a detailed exploration of residential buildings.

Norman et al. (2006) compared the energy use for high and low residential density and found that the choice of functional unit is relevant to a full understanding of urban density effects. Their results show that the energy demand for building operation in a low-density suburban development is more energy intensive than high-density urban core development by a factor of 2.0-2.5 on a per capita basis. However, when the functional unit is changed to a per unit of living space basis the factor decreases to a value between 1.0 and 1.5 (pp. 18-19).

\section{Studies on building form and energy demand}

Tereci et al. (2013) studied the impact of building typology on building energy demand and showed that there is a strong correlation between building form and operational energy demand. The heating demand of a single-family home was shown to be approx. 25 per cent higher than that of a high-rise block with the same insulation standard (pp. 97-99).

Puurunen and Organschi (2013) compared a suburban single-family home with an apartment of similar size and concluded that, considered over a lifespan of 50 years, a concrete-built apartment in a mid-rise multi-family house has a lower primary energy demand[1] than a timber framed single-family home of the same thermal standard (pp. 191-193). However, data for operational energy use were derived from statistics and norms and was not adjusted to the constructions investigated in the life cycle analysis (p. 190).

\section{Studies on building location and energy demand}

According to the final report of the Global Energy Assessment (GEA) in 2012 the final energy demand[2] for heating and cooling is $155 \mathrm{kWh} / \mathrm{m}^{2}$ a for average existing multifamily homes and $160 \mathrm{kWh} / \mathrm{m}^{2}$ a for average existing single-family homes in warm moderate climate regions of Western Europe. For cold moderate climate regions in Western Europe the respective energy demand sums up to $225 \mathrm{kWh} / \mathrm{m}^{2}$ a for multi-family homes and $261 \mathrm{kWh} / \mathrm{m}^{2}$ a for single-family homes. For new buildings a standard of 50 $\mathrm{kWh} / \mathrm{m}^{2}$ and year has been assumed for all climates and building types (see Uerge-Vorsatz et al., 2012, pp. 706-708). Though not further specified by the authors, it is assumed that these values refer to the total floor area (TFA), as this is the most common reference value in statistics related to buildings.

A survey published by the Buildings Performance Institute Europe (BPIE) examined the energy performance of the building stock of the European Union, Switzerland and Norway. For the purpose of this survey the countries were grouped into three larger regions: North and West, Central and East (former countries of the Eastern bloc) and South. According to survey data, the final space heating energy demand for recently constructed single-family houses ranges between $53 \mathrm{kWh} / \mathrm{m}^{2}{ }_{\text {UFA }}$ a (Germany) and $124 \mathrm{kWh} / \mathrm{m}^{2}{ }_{\mathrm{UFA}}$ a (Sweden) in Northern and Western Europe, between $68 \mathrm{kWh} / \mathrm{m}^{2}{ }_{U F A}$ (Portugal) and $95 \mathrm{kWh} / \mathrm{m}^{2}{ }_{\mathrm{UFA}} \mathrm{a}$ (Italy) in Southern Europe, and between $34 \mathrm{kWh} / \mathrm{m}^{2}{ }_{U F A}$ a (Slovenia) and $101 \mathrm{kWh} / \mathrm{m}^{2}{ }_{U F A}$ a (Bulgaria) in Central and Eastern Europe (see BPIE, 2011, pp. 46-47). It should be noted that only the building stock of a few member states has been assessed and that the considered periods of construction were different for each country. Further energy demand, such as cooling and household electricity, was not assessed for residential buildings.

A database on the energy demand of European building stock can be found in the TABULA WebTool[3], which gives an overview of European residential buildings, sorted by typology and construction year. The primary energy demand for heating for recent (newer than 2001) Austrian residential buildings listed in this study ranges between 74 and $104 \mathrm{kWh} / \mathrm{m}^{2}{ }_{\text {UFA }}$ a. For Greece these values range between 56 and $160 \mathrm{kWh} / \mathrm{m}^{2}{ }_{\text {UFA }}$ a and for Ireland between 40 and $105 \mathrm{kWh} / \mathrm{m}^{2}{ }_{\text {UFA }}$ a (see also: Loga et al., 2016). 
Another online database on European building stock can be found at ENTRANZE[4]. This database summarises building related statistical data from several sources in an interactive map. According to this database the final energy consumption per $\mathrm{m}^{2}$ residential area varies between $69 \mathrm{kWh} / \mathrm{m}^{2}{ }_{\text {UFA }} \mathrm{a}$ (Malta) and $381 \mathrm{kWh} / \mathrm{m}^{2}{ }_{\text {UFA }} \mathrm{a}$ (Luxembourg). The countries mentioned in the present paper show the following energy consumption: Austria: $231 \mathrm{kWh} / \mathrm{m}^{2}{ }_{U F A}$ a, Ireland: $197 \mathrm{kWh} / \mathrm{m}^{2}{ }_{U F A}$ a, Finland: $304 \mathrm{kWh} / \mathrm{m}^{2}{ }_{U F A}$ a, Greece: $202 \mathrm{kWh} / \mathrm{m}^{2}{ }_{\mathrm{UFA}} \mathrm{a}$. These numbers are average values for all residential buildings in these countries and do not reflect today's standards.

\section{Methodology}

In this study the thermal energy demand[5] for space conditioning was determined by dynamic thermal simulations, all carried out with the IES Virtual Environment (IESVE) suite. IESVE is an energy analysis and performance modelling software used for dynamic thermal and energy simulations of buildings. It has been extensively validated and assessed against a number of global as well as regional standards[6]. The simulation results represent the specific heating and cooling energy demand or thermal energy demand in kilowatt hours per $\mathrm{m}^{2}$ usable floor area (UFA) and year $\left(\mathrm{kWh} / \mathrm{m}^{2} \mathrm{UFA}\right.$ a).

The current definition of urban density on an architectural scale employs the ratio of the TFA to the building site area (SA) - the so-called floor area ratio (FAR). In the research work described here, the ratio of UFA to building SA is employed instead, as it is the UFA and not the TFA, which determines the number of people which can be accommodated in a given urban area. For the purposes of this study, the usable area per person is assumed to be the same for all typologies. This allows an unbiased comparison of the energy performance independent of differences in the specific floor area per person for the various typologies and the different locations (for data on average household sizes depending on typology and location see BPIE, 2011, pp. 27-31). The value assumed in this study is $45 \mathrm{~m}^{2}$ per person, corresponding to the average net dwelling area per person in Austria (Statistics Austria, 2017b). Based on this assumption, a comparison of energy demand based on floor area and a comparison based on a per capita basis yield the same result.

Despite the well-known discrepancy between predicted building energy performance based on simulation results and actual measured energy performance, which is largely accounted to unpredicted occupant behaviour (Cali et al., 2016; Karjalainen, 2016; Nguyen and Aiello, 2013; Martinaitis et al., 2015; Schakib-Ekbatan et al., 2015), simulation was chosen for these investigations, as it allows to investigate the behaviour of different building types relative to one another under the same boundary conditions which then again allows to study the effect of building typology on energy performance in isolation from other parameters. The results are to be used to evaluate the relative performance of the different typologies and not to predict the absolute energy demand in operation.

The study builds upon generic buildings. Still, these buildings were planned in such detail, that they provide fully functional floor plans and comply with national building regulations. This approach allows us to draw conclusions on the scale of individual buildings and at an urban scale at the same time.

To evaluate the operational energy demand, the thermal models of the investigated building typologies were placed in an urban pattern of uniform buildings (see Figures 2 and 3). For better comparability and scalability all investigated typologies were designed to fit into a rectangular urban grid of $125 \times 125 \mathrm{~m}$. For the same reasons all typologies employ the same building constructions (see chapter "Construction materials data"). The ventilation concept and thus the fan energy is assumed to be the same for all typologies. The influence of the typology on lighting energy demand is assumed to be small and is therefore not considered in this study. 
SASBE $7,3 / 4$

230

\section{Model assumptions}

For the calculation of the total household energy demand or final energy demand it is assumed that heating and cooling is carried out by an electrical heat pump system with geothermal source/sink and that the geothermal potential in all typologies is sufficient to cover heating energy demand (vertical boreholes). An average annual coefficient of performance of 3 is assumed. The final electrical energy demand for heating and cooling is thus assumed to be the total thermal energy demand divided by 3 (see Table XIX).

A final electrical energy demand of $45 \mathrm{kWh} / \mathrm{m}^{2} \mathrm{UFA}_{\mathrm{A}}$ a for lighting, ventilation, household appliances and domestic hot water services (DHWS) is assumed. This assumption is close to the average annual electricity demand of Austrian households (Statistics Austria, 2017a).

This approach allows us to convert the total final energy demand into electrical energy, which is assumed to be the main form of renewable energy in future energy grids, and thus easily compare the total energy demand to the potential for on-site renewable energy production.

\section{Investigated building typologies}

Both the perimeter block development with a building depth of $15 \mathrm{~m}$ and the high-rise buildings with a façade to core distance of $9.5-11.5 \mathrm{~m}$ were designed as usage-neutral structures, which allow other uses besides residential use such as for office space. Both typologies have a floor-to-floor height of $3.5 \mathrm{~m}$. The chosen design allows a wide variety of different apartment sizes. The living areas are oriented towards all directions. The detached house typologies on the other hand have a floor-to-floor height of $3 \mathrm{~m}$, as these serve primarily for residential use. Each residential unit has one dedicated car-parking space and one dedicated storeroom. All three types have a private outdoor space in the form of a private garden or balconies.

Typology $A$. In any attempt to achieve high urban density, the high-rise typology is obviously a likely candidate. The configuration considered here comprises 26-story

Figure 2.

Urban pattern of the investigated typologies
Figure 3.

Simulation models of typology A, B and C
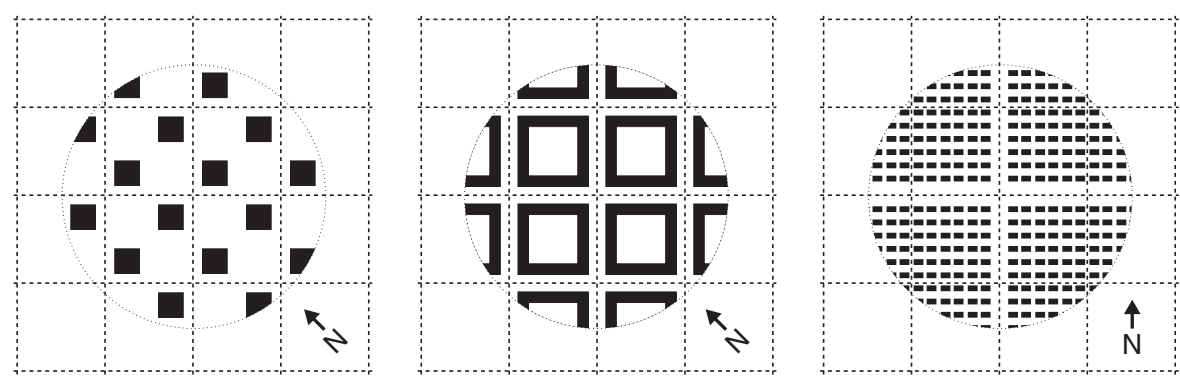

Notes: Left: typology A - high-rise residential towers. Centre: typology B - perimeter block development. Right: typology $\mathrm{C}$ - single-family homes. Raster distance: $125 \mathrm{~m}$
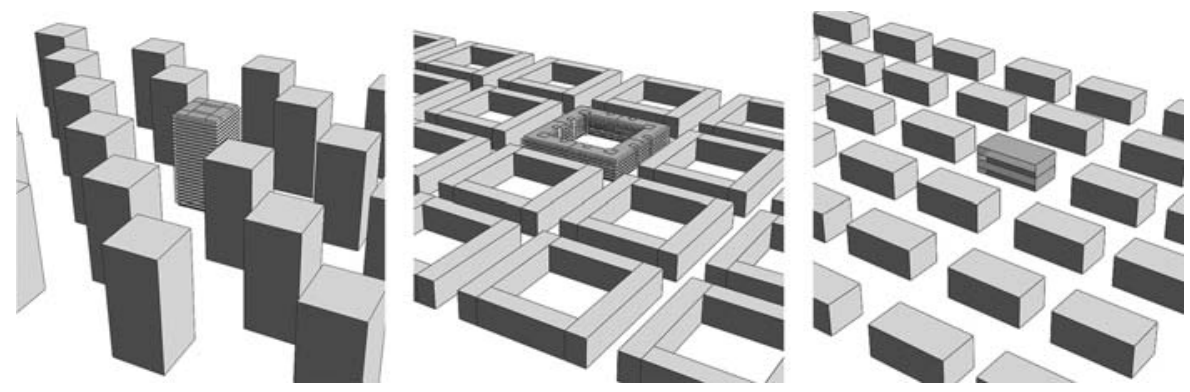
high-rise residential towers (see Figures 4-7 and Table I), which are arranged to allow a $45^{\circ}$ daylight access angle (see Figures 6 and 7 ). The grid is skewed to improve solar access (see Figure 2, left). The building facades face north-east (NE), south-east (SE), south-west (SW) and north-west (NW), so that all apartments receive sunlight at some time of the day. The rectangular floor plan of the towers measures $35 \mathrm{~m} \times 35 \mathrm{~m}$. The central core measures $16 \mathrm{~m} \times 12 \mathrm{~m}$. The towers are organised with apartments on all four sides of a square floor plan and accessed by internal circulation corridors (see Figure 5). Due to the height of the building, two escape staircases and one firefighters lift are provided (according to

Residential building typologies

231 Austrian Institute of Construction Engineering (OIB), 2015, pp. 7-8). There are $2 \mathrm{~m}$ deep balconies on all sides of the buildings, which provide direct access to an outdoor space for the occupants (see Figures 4 and 5).

Typology $B$. The second typology chosen represents a typical European city model, employing a medium rise perimeter block development with courtyards (cf. Oikonomou, 2014, p. 490). The buildings are organised in seven-storey blocks with side dimensions of $100 \mathrm{~m} \times 100 \mathrm{~m}$ (see Figures 8-11 and Table II). The building depth is $15 \mathrm{~m}$ so that the courtyards are $70 \mathrm{~m}$ deep (see Figure 8 ). The blocks are spaced apart such that the angle for daylight is $45^{\circ}$ as above (see Figures 10 and 11). The grid is also arranged as in Typology A such that there are no north facades (see Figure 2, centre). There are $2 \mathrm{~m}$ deep balconies on all sides of the buildings, which provide direct access to an outdoor space for the occupants (see Figures 8 and 9). The building complex provides three to five apartments per floor and staircase (see Figure 9). A building height of 7 floors was chosen, so the highest evacuation level is less than $22 \mathrm{~m}$ above ground. Thus the high-rise building limit is not exceeded and additional fire protection measures are not required (according to OIB, 2015, pp. 2-6).

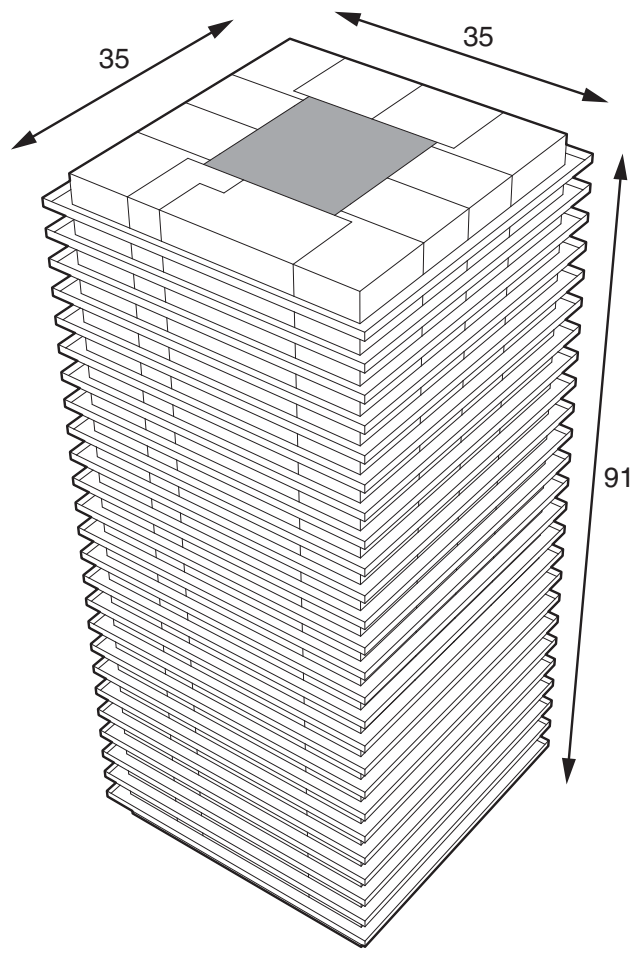

Figure 4. Geometry of typology A 
SASBE

7,3/4

232

Figure 5.

Typical floor plan of typology A

Figure 6.

Urban integration of typology A
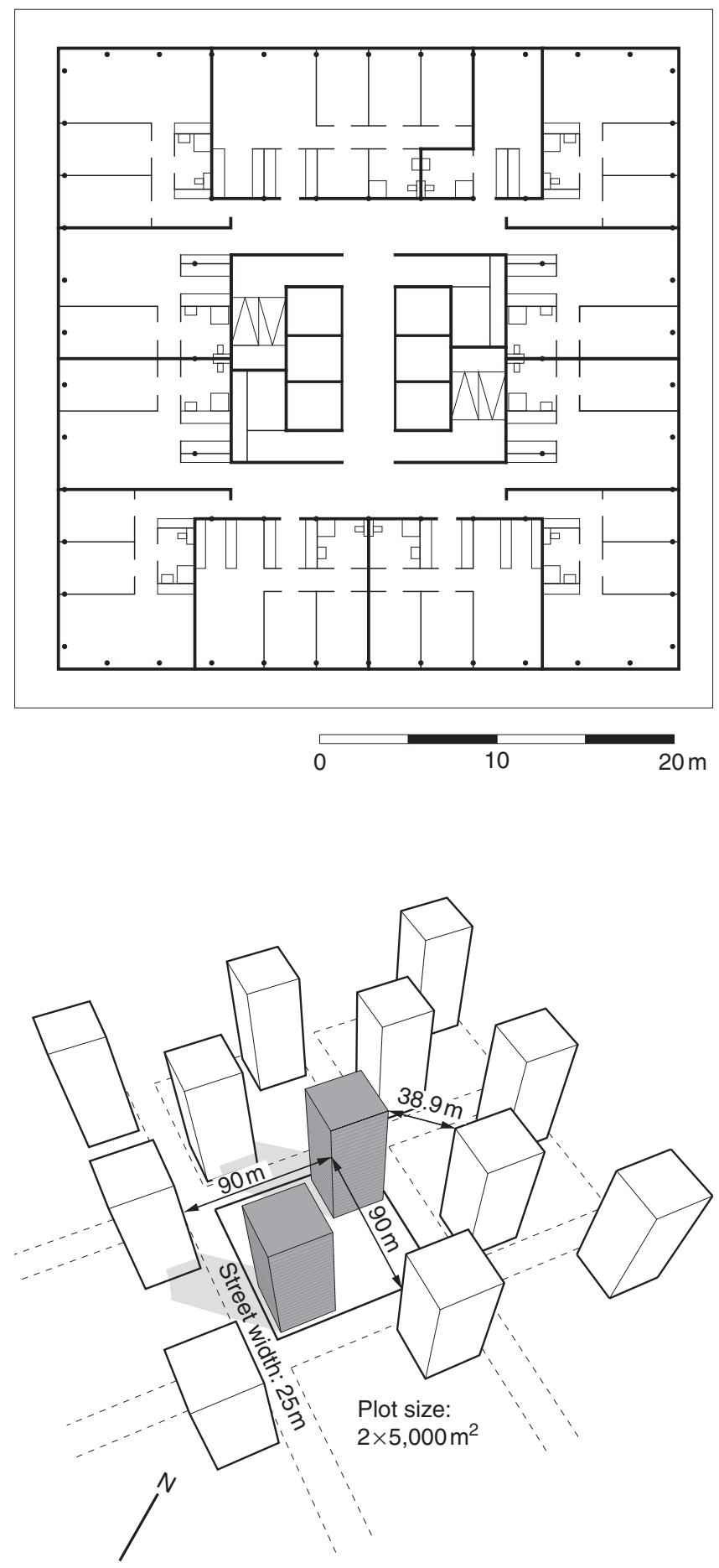


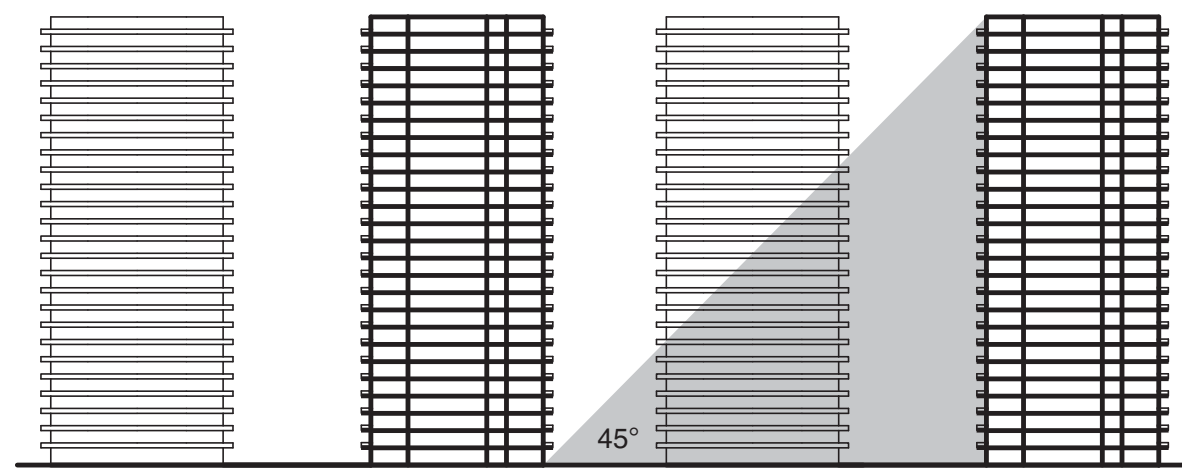

Note: The buildings are spaced apart to allow a $45^{\circ}$ daylight access angle
Residential building typologies

233

Figure 7.

Schematic section through typology A

Typology A

Number of floors

Clear height of internal spaces

Building height

Glazed façade area (as seen from inside)

Site area (SA)

Total floor area (TFA)

Usable floor area (UFA)

Ground cover ratio

Space efficiency factor (UFA/TFA)

Floor to area ratio $(\mathrm{FAR}=\mathrm{TFA} / \mathrm{SA})$

Usable floor area to site area (UFA/SA)

Dwellings per hectare (at $90 \mathrm{~m}^{2} \mathrm{UFA} / \mathrm{dwelling}$ )

Population Density (persons/ha, at $45 \mathrm{~m}^{2} \mathrm{UFA} /$ person)

Table I.

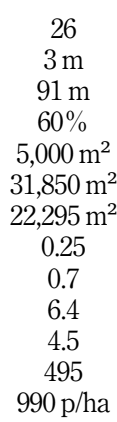

Specifications of typology A

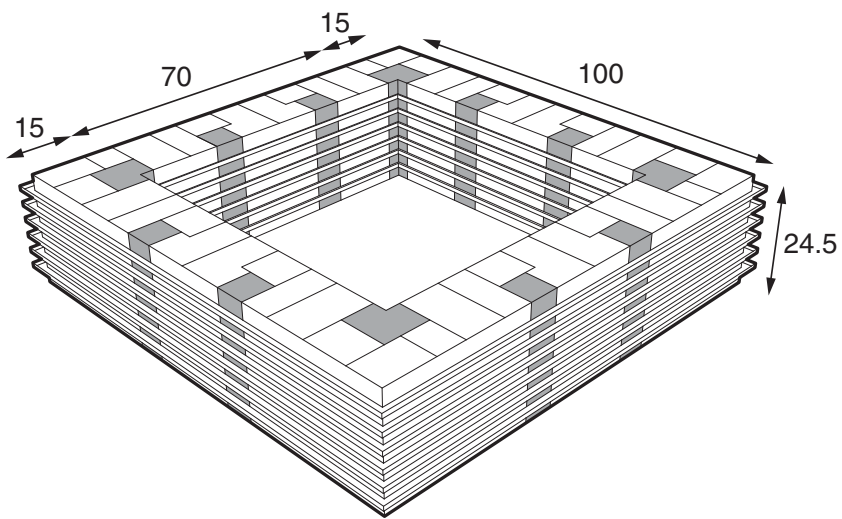

Figure 8.

Geometry of typology B

Typology $C$. Typology C comprises single-family homes. This model was chosen for investigation as numerous studies have shown that this is the preferred housing type for a large proportion of the population in many different parts of the world, for example in Austria and the USA (Zellmann and Mayrhofer, 2013, pp. 8-11 Belden Russonello and Stewart LLC, 2011, pp. 17-19). In an attempt to investigate whether this desire could 
SASBE

$7,3 / 4$

234

Figure 9.

Typical floor plan of typology B

Figure 10.

Urban integration of typology B

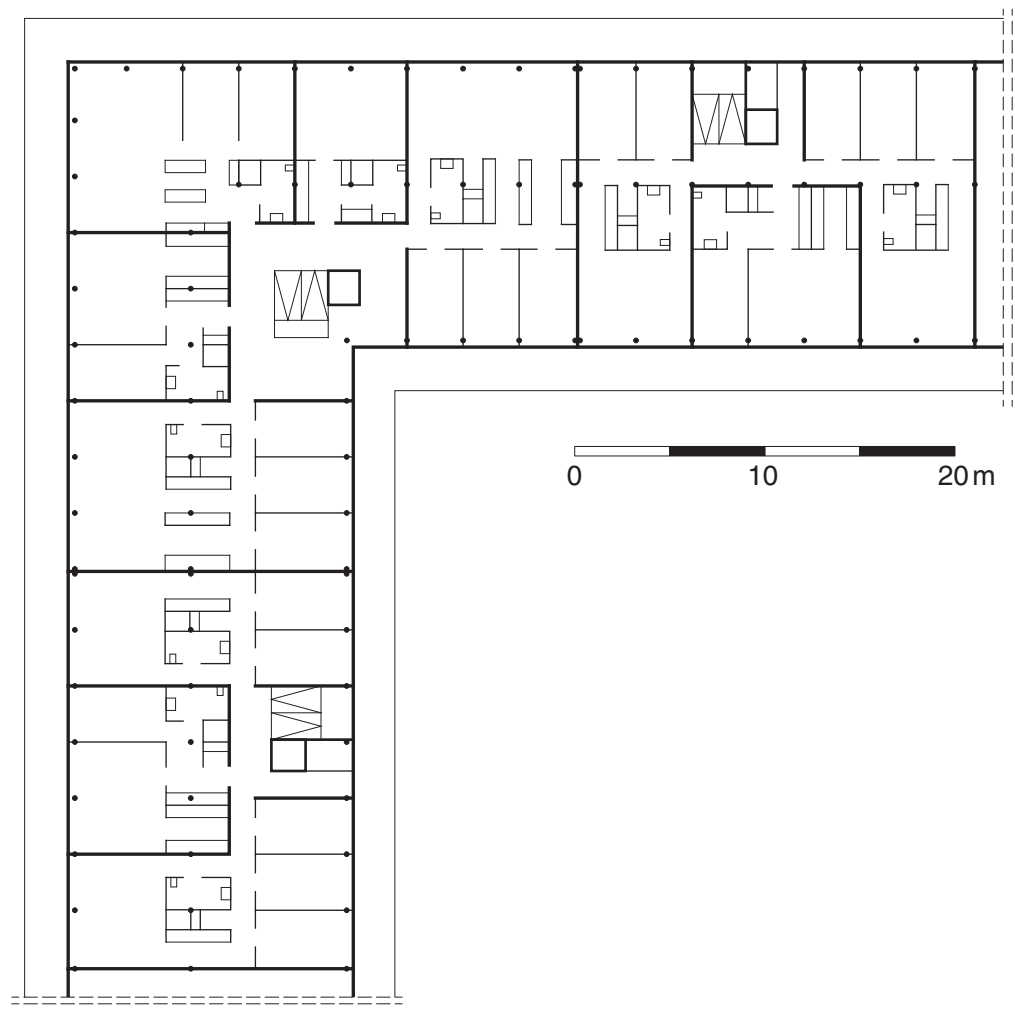

Note: The plan represents a quarter of the whole building

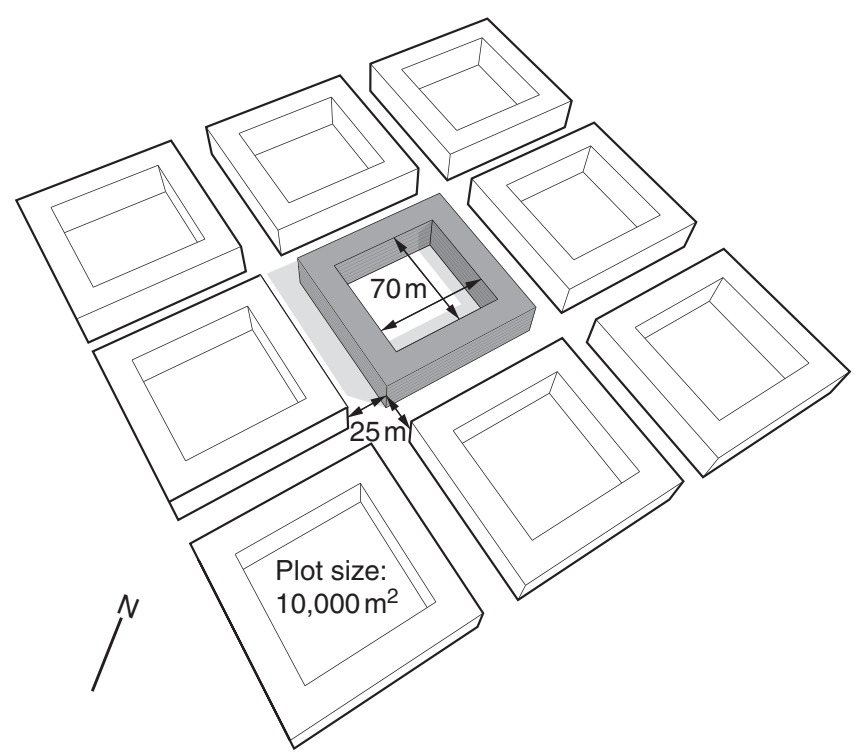


hypothetically be accommodated without the excessive use of resources, a compact single-family home typology on small plots was developed (see Figures 12-15 and Table III). It should be noted that this model does not represent the majority of single-familydwelling urban typologies employed in cities presently, with the major difference being the much smaller plot size. Nevertheless, it could arguably provide its occupants with the main attributes responsible for the preference for the single-family home typology. The SA is approximately $300 \mathrm{~m}^{2}$ and the buildings are laid out such that the sunlight access angle is $27.5^{\circ}$ (see Figures 14 and 15). Thus the spaces will receive more sunlight in winter than those in the typologies described above. The buildings are two-storey structures orientated with the long axis east west such that the main facades face directly north $(\mathrm{N})$ and south $(\mathrm{S})$. The house is designed as a two-storey building without a basement. Parking (carport) and storage areas are located in a separate thermally unconditioned structure at the north side of the building (see Figure 13) and were not considered in the area and density calculations (see Table III). To reduce unwanted views between the houses and for optimal insolation all living rooms are oriented to the south side (see Figure 13).

\section{Construction materials data}

For better comparability all typologies employ the same building constructions and thermal properties. Thermal mass is provided in the form of the exposed undersides of concrete

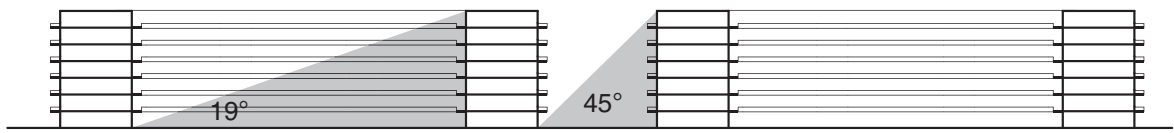

Note: The buildings are spaced apart to allow a $45^{\circ}$ daylight access angle

Figure 11. Schematic section through typology B

Typology B

Number of floors

Clear height of internal spaces

Building height

Glazed façade area (as seen from inside)

Site area (SA)

Total floor area (TFA)

Usable floor area (UFA)

Ground cover ratio

Space efficiency factor (UFA/TFA)

Floor to area ratio $(\mathrm{FAR}=\mathrm{TFA} / \mathrm{SA})$

Usable floor area to site area (UFA/SA)

Dwellings per ha (90 $\mathrm{m}^{2} \mathrm{UFA} /$ dwelling)

Population density ( $45 \mathrm{~m}^{2} \mathrm{UFA} /$ person)
Residential building typologies

235
Table II.

Specifications of typology B

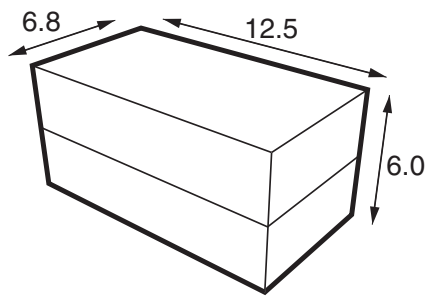

Figure 12.

Geometry of typology $\mathrm{C}$ 
SASBE

$7,3 / 4$

\section{6}

Figure 13.

Typical floor plans of typology C

Figure 14.

Urban integration of typology $\mathrm{C}$

Figure 15.

Schematic section through typology C

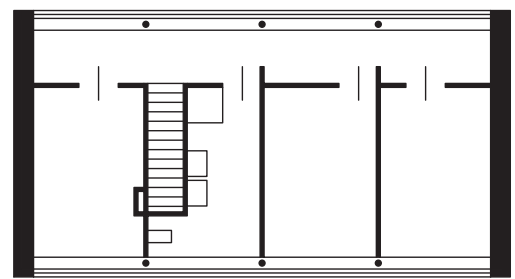

First floor

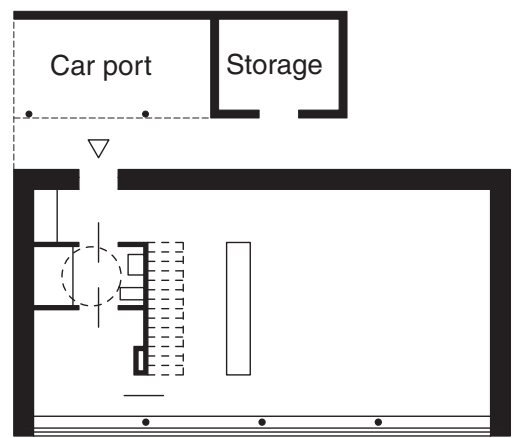

Ground floor
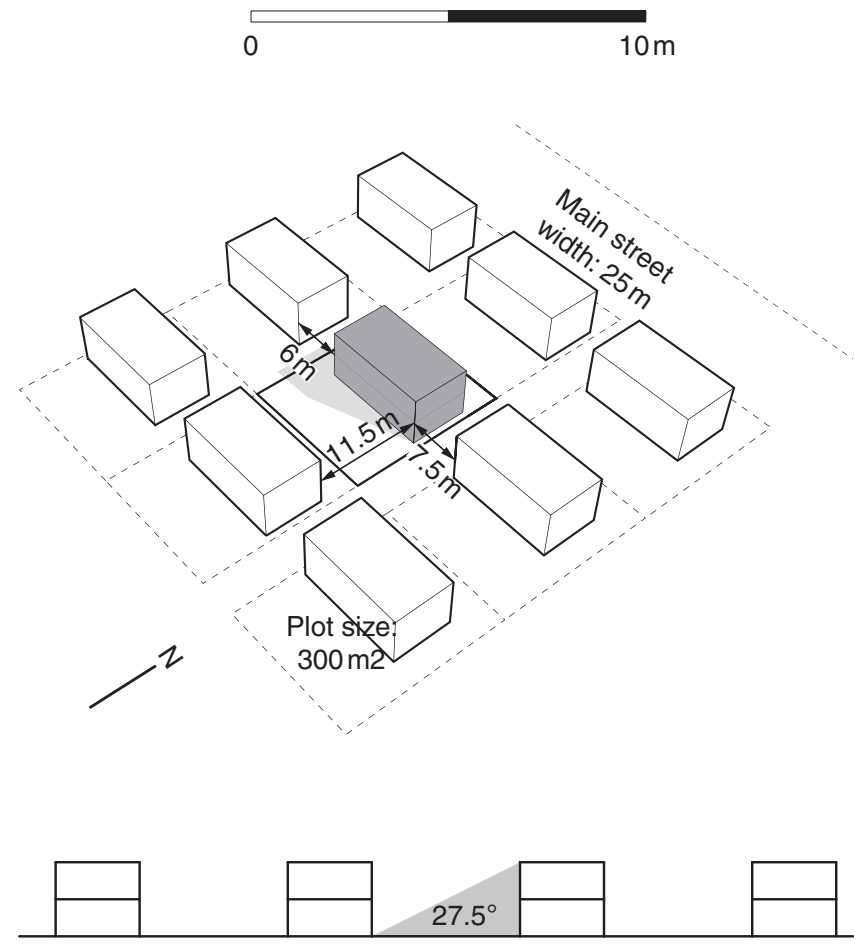

Note: The buildings are spaced apart to allow a $27.5^{\circ}$ daylight access angle 
Typology C

Number of floors

Clear height of internal spaces

Building height

Glazed area, south façade (as seen from inside)

Glazed area, north façade (inside)

Glazed area, east \& west façade (inside)

Site area (SA)

Total floor area (TFA)

Usable floor area (UFA)

Ground cover ratio

Space efficiency factor (UFA/TFA)

Floor to area ratio $(\mathrm{FAR}=\mathrm{TFA} / \mathrm{UFA})$

Usable floor area to site area (UFA/SA)

Dwellings per hectare $\left(90 \mathrm{~m}^{2} \mathrm{UFA} / \mathrm{dwelling}\right)$

Population density ( $45 \mathrm{~m}^{2} \mathrm{UFA} /$ person)

2

$2.5 \mathrm{~m}$

$6.5 \mathrm{~m}$

$60 \%$

$10 \%$

$0 \%$

$300 \mathrm{~m}^{2}$

$170 \mathrm{~m}^{2}$

$141 \mathrm{~m}^{2}$

0.28

0.83

0.57

0.47

52

$104 \mathrm{p} / \mathrm{ha}$
Residential building typologies

237

Table III

Specifications of typology C

ceiling slabs. Properties of the building envelope are defined in: Tables IV-X. Wall constructions are described from outside to inside, horizontal constructions from the uppermost to the lowermost layer.

Solar shading is taken into account via external blinds, which are lowered when the external temperature is greater than $24^{\circ} \mathrm{C}$. The transmission factor for direct radiation varies from 0.65 at a $0^{\circ}$ incident angle to 0.00 at an incident angle of $45^{\circ}$ or greater.

\begin{tabular}{lcr}
\hline Material & $\begin{array}{c}\text { External walls } \\
\text { Thickness }(\mathrm{mm})\end{array}$ & $\lambda(\mathrm{W} / \mathrm{mK})$ \\
\hline External plaster & 5 & 0.500 \\
Thermal insulation & 80 & 0.035 \\
Insulating brick & 250 & 0.270 \\
Gypsum plastering & 10 & 0.420 \\
$U$-value & $0.30\left(\mathrm{~W} / \mathrm{m}^{2} \mathrm{~K}\right)$ &
\end{tabular}

Table IV. Layer structure of external walls (from outside to inside)

\begin{tabular}{lccc}
\hline Material & Roof & & \\
Thickness $(\mathrm{mm})$ & $1 \mathrm{~W} / \mathrm{mK})$ & & $\begin{array}{r}\text { Table V. } \\
\text { Thermal insulation }\end{array}$ \\
$\begin{array}{lcc}\text { Reinforced concrete } \\
U \text {-value }\end{array}$ & 200 & 0.035 & $\begin{array}{r}\text { Layer structure } \\
\text { of roofs (from } \\
\text { top to bottom) }\end{array}$ \\
\hline
\end{tabular}

\begin{tabular}{|c|c|c|c|}
\hline Material & $\begin{array}{l}\text { Internal floor slabs } \\
\text { Thickness (mm) }\end{array}$ & $\lambda(\mathrm{W} / \mathrm{mK})$ & \\
\hline Timber flooring & 10 & 0.140 & \\
\hline Screed & 60 & 1.150 & Table VI. \\
\hline Mineral fibre & 25 & 0.035 & Layer structure of \\
\hline Reinforced concrete & 180 & 2.300 & internal floor slabs \\
\hline$U$-value & $0.90\left(\mathrm{~W} / \mathrm{m}^{2} \mathrm{~K}\right)$ & & (from top to bottom) \\
\hline
\end{tabular}


SASBE

$7,3 / 4$

238

Table VII.

Layer structure

of party walls

\section{Internal loads}

With regard to internal gains, one person per $45 \mathrm{~m}^{2}$ is assumed with a 50 per cent reduction of this occupation density between 8 a.m. and 5 p.m. A constant heat output of $3.5 \mathrm{~W} / \mathrm{m}^{2}$ is assumed for electrical loads. It should be noted that a study carried out by Elsland et al. (2014) revealed that the contribution of internal heat gains to meeting thermal heat demand is often underestimated. Their survey of internal gains in a broad range of dwellings in European residential buildings indicated a range between 3.8 and $6.6 \mathrm{~W} / \mathrm{m}^{2}$ average constant load, including heat gain from people (p. 37). The value of approx. $5.1 \mathrm{~W} / \mathrm{m}^{2}$ in this study lies in the middle of this range.

\section{HVAC systems}

With regard to ventilation, 12.5 litres per second outdoor air supply per person is assumed, which equates to 0.4 air changes per hour for one person per $45 \mathrm{~m}^{2}$ and a room height of $2.5 \mathrm{~m}$ or 0.33 air changes per hour for a room height of $3 \mathrm{~m}$. This is assumed to be achieved by a combination of a mechanical extract system with natural supply via elements integrated into the facade supplying 0.18 litres per second per $\mathrm{m}^{2} \mathrm{UFA}$, together with a constant infiltration rate of $0.10 \mathrm{l} / \mathrm{s}$ per $\mathrm{m}^{2}$ UFA. In the common areas (staircase, corridors)

\begin{tabular}{lcc}
\hline Material & $\begin{array}{c}\text { Party walls } \\
\text { Thickness }(\mathrm{mm})\end{array}$ & $\lambda$ (W/Mk) \\
\hline Plasterboard & 25 & 0.200 \\
Sound insulation & 18 & 0.035 \\
Plasterboard & 25 & 0.200 \\
U-value & $0.18\left(\mathrm{~W} / \mathrm{m}^{2} \mathrm{~K}\right)$ & \\
\hline
\end{tabular}

\begin{tabular}{lcc}
\hline Material & $\begin{array}{c}\text { Ground floor slab } \\
\text { Thickness }(\mathrm{mm})\end{array}$ & $\lambda(\mathrm{W} / \mathrm{mK})$ \\
\hline Timber flooring & 10 & 0.140 \\
Screed & 60 & 0.410 \\
Sound insulation & 25 & 0.035 \\
Reinforced concrete & 250 & 2.300 \\
Mineral fibre & 125 & 0.035 \\
$U$-value & $0.20\left(\mathrm{~W} / \mathrm{m}^{2} \mathrm{~K}\right)$ & \\
\hline
\end{tabular}

\section{Table IX.}

Assumptions for the floor over the garage (from top to bottom, type A and B only)
Floor over garage

Layer composition same as floor against ground temperature garage $=$ external temp
$U$-value
$0.20\left(\mathrm{~W} / \mathrm{m}^{2} \mathrm{~K}\right)$

Table X.

Assumptions for the fenestration
Double glazed argon-filled cavity low-e coating

\section{Fenestration}

$U$-value (total)

SHGC

$1.30\left(\mathrm{~W} / \mathrm{m}^{2} \mathrm{~K}\right)$ 0.65 
an infiltration rate of 0.2 air changes per hour was assumed. To allow free cooling in hot weather, windows are assumed to be opened when the internal temperature is both greater than $24^{\circ} \mathrm{C}$ and greater than the external temperature.

Further assumptions regarding the building HVAC systems are as follows:

Residential building typologies

- heating set point (apartments): $20^{\circ} \mathrm{C}$ with night setback $16^{\circ} \mathrm{C}$;

- cooling set point (apartments): $26^{\circ} \mathrm{C}$;

- humidity control setpoints (apartments): 30 per cent min., 60 per cent max.;

- staircases and common areas are not thermally conditioned; and

- for the purposes of this study the temperature in the underground garages was assumed to be the same as the outside temperature.

\section{Simulated locations}

Dynamic thermal energy simulations were carried out for the following four locations in Europe:

(1) Helsinki, Finland $60^{\circ} \mathrm{N}$.

(2) Dublin, Ireland $53^{\circ} \mathrm{N}$.

(3) Vienna, Austria $48^{\circ} \mathrm{N}$.

(4) Athens, Greece $38^{\circ} \mathrm{N}$.

The four locations selected represent the wide diversity of different climates in Europe and were chosen with the intention of obtaining insight into the effect of climatic conditions on the results. Simulation results are shown in Figure 16 and in Tables XI-XIII.

\section{Renewable energy production}

The renewable energy production potential via building integrated photovoltaic modules (PV) on the roof and the S, SW and SE facing facades was estimated for the various typologies (see Tables XVI-XVIII). For the estimation, the average annual insolation (I) on each surface was multiplied by the area of photovoltaics (PV) and an efficiency factor $(\eta)$ of 0.15 resulting in the annual production potential (PP). The annual embodied energy (AEE) demand[7] was then offset against the PP and the divided by the UFA of the building which then results in the total annual energy production (TAEP), based on UFA.

The incident solar radiation on the variously orientated vertical facades and the horizontal roof area was calculated with the IESVE suite. The AEE of the solar energy production system was assessed according to the Swiss norm SIA 2032:2010 (Swiss Society of Engineers and Architects, 2010, 2013), based on a lifecycle of 30 years (see Table XV).

\section{External electrical energy demand (EEED)}

The sum of the heat pump electrical energy demand and the electrical energy demand for lighting, ventilation, household appliances and DHWS, based on the assumptions outlined above, gives the total electrical energy demand for the building. The difference between this value and the on-site renewable energy production (TAEP) gives the EEED for the various typologies and locations (see Table XIX and Figure 17). Negative values for EEED imply that the annual electrical energy production of the building integrated PV system exceeds the annual electrical energy demand. This excess energy could be supplied to the grid or stored on site with a suitable storage system. 
SASBE

$7,3 / 4$

240

\section{Results}

Thermal energy demand

The results of the simulations are given in Tables XI-XIII and are compared to each other in Figure 16. The simulation results show, that the single-family home typology (type C) has the highest thermal energy demand in all simulated climatic environments $(22.1-85.2 \mathrm{kWh} /$ $\mathrm{m}^{2}{ }_{\mathrm{UFA}} \mathrm{a}$, depending on location, see Table XIII), while the thermal energy demand for the multi-family typologies (type A and B) are very similar in all environments (differences between 3 and 5 per cent, depending on location, see Tables XI and XII). The gap between the multi-family and single-family types is the highest in Helsinki (37 per cent higher than the best result) and the lowest in Vienna (19 per cent higher than the best result, see Figure 16).

To better understand the influence of shading by the adjacent buildings the simulations were also carried out for the three typologies using the Vienna climate data without consideration of the neighbouring buildings with the results shown in Table XIV. As expected, the influence of shading on the thermal energy demand rises with the density of the urban structure, described by the FAR (compare to Tables I-III).

\section{Renewable energy production}

As could be expected, roof surfaces receive the highest incident solar radiation in all examined locations, with rising intensity towards lower latitudes (between 940 and

\begin{tabular}{lccc}
\hline $\begin{array}{l}\text { Typology A: high } \\
\text { rise residential tower }\end{array}$ & $\begin{array}{c}\text { Annual heating } \\
\text { energy demand } \\
\left(\mathrm{kWh} / \mathrm{m}^{2} \mathrm{UFA}\right)\end{array}$ & $\begin{array}{c}\text { Annual cooling } \\
\text { energy demand } \\
\left(\mathrm{kWh} / \mathrm{m}^{2} \text { UFA }\right)\end{array}$ & $\begin{array}{c}\text { Annual thermal } \\
\text { energy demand } \\
\left(\mathrm{kWh} / \mathrm{m}^{2} \text { UFA }\right)\end{array}$ \\
\hline Helsinki $60^{\circ} \mathrm{N}$ & 60.8 & 0.8 & 61.6 \\
Dublin $53^{\circ} \mathrm{N}$ & 19.6 & 0.4 & 20.0 \\
Vienna $48^{\circ} \mathrm{N}$ & 28.0 & 3.9 & 31.9 \\
Athens $38^{\circ} \mathrm{N}$ & 1.9 & 15.7 & 17.6 \\
\hline
\end{tabular}

Table XI.

Thermal energy demand for typology A

\section{Typology B: perimeter block} development
Annual heating energy Annual cooling energy Annual thermal energy demand demand demand $\left(\mathrm{kWh} / \mathrm{m}_{\mathrm{UFA}}^{2}\right)$

$\left(\mathrm{kWh} / \mathrm{m}^{2} \mathrm{UFA}\right)$

Table XII.

Thermal energy demand for typology B
Helsinki $60^{\circ} \mathrm{N}$

Dublin $53^{\circ} \mathrm{N}$

Vienna $48^{\circ} \mathrm{N}$

Athens $38^{\circ} \mathrm{N}$
63.1

20.4

28.9

2.2
0.7

0.5

4.0

14.9
$\left(\mathrm{kWh} / \mathrm{m}^{2} \mathrm{UFA}\right)$

63.8

20.9

32.9

17.1

\begin{tabular}{lccc}
\hline Typology C: single-family & $\begin{array}{c}\text { Annual heating energy } \\
\text { demand } \\
\left(\mathrm{kWh} / \mathrm{m}^{2} \text { UFA }\right)\end{array}$ & $\begin{array}{c}\text { Annual cooling energy } \\
\text { demand } \\
\left(\mathrm{kWh} / \mathrm{m}^{2} \text { UFA }\right)\end{array}$ & $\begin{array}{c}\text { Annual thermal energy } \\
\text { demand } \\
\left(\mathrm{kWh} / \mathrm{m}^{2} \text { UFA }\right)\end{array}$ \\
\hline home & 83.8 & 1.4 & 85.2 \\
Helsinki $60^{\circ} \mathrm{N}$ & 24.2 & 0.6 & 24.8 \\
Dublin $53^{\circ} \mathrm{N}$ & 32.9 & 5.2 & 38.1 \\
Vienna $48^{\circ} \mathrm{N}$ & 3.6 & 18.5 & 22.1 \\
Athens $38^{\circ} \mathrm{N}$ & & &
\end{tabular}




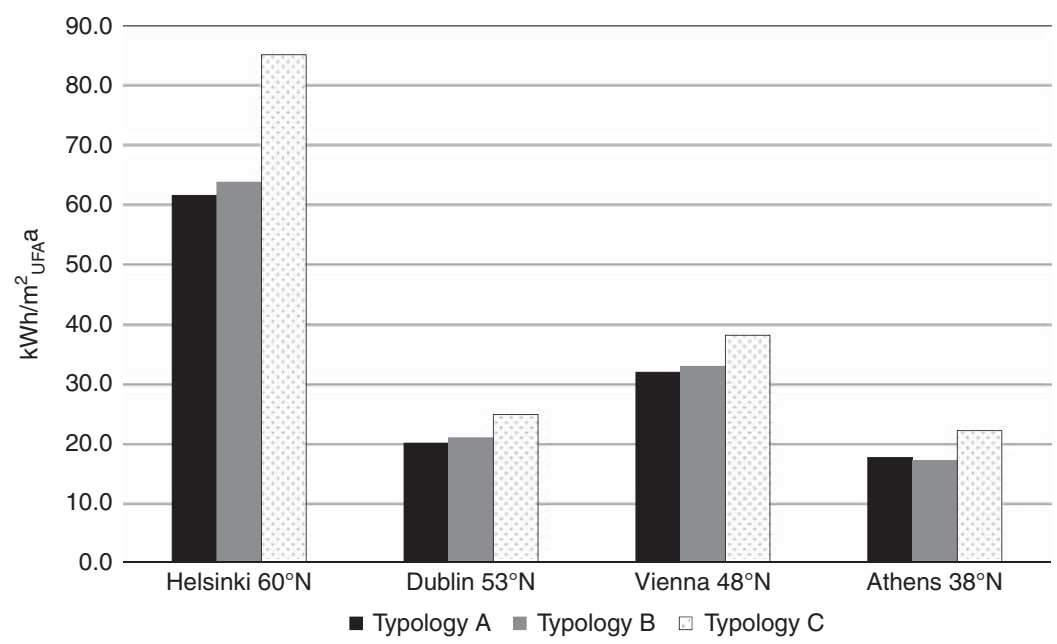

Residential building typologies

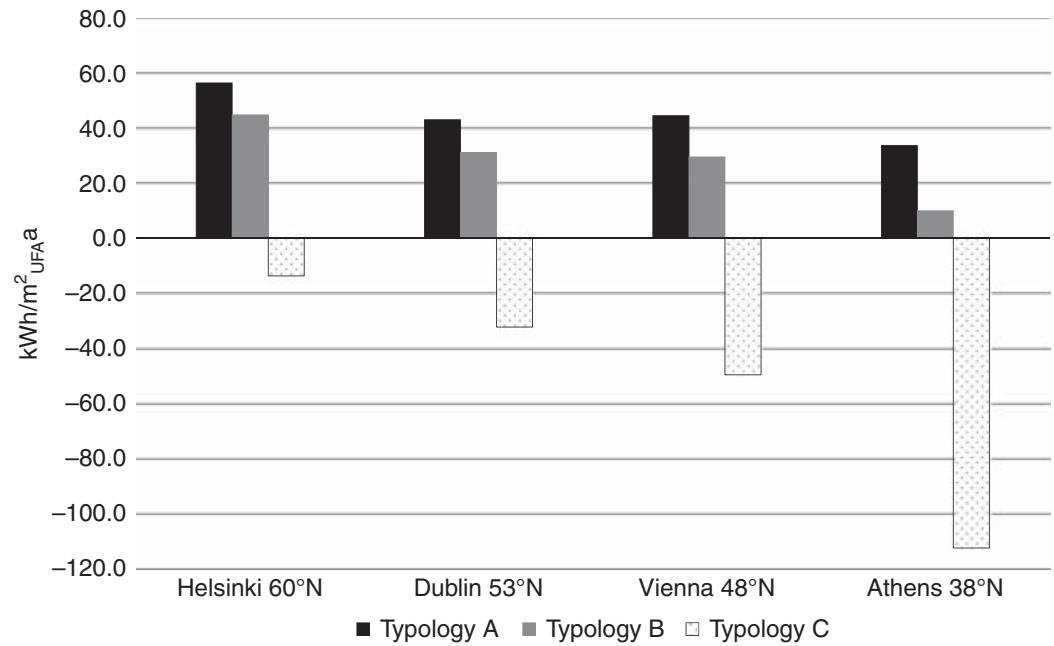

Figure 16.

Thermal energy demand for all

investigated typologies and locations

Figure 17

Total estimated annual External Electrical Energy

Demand (EEED) for all investigated typologies and locations

Table XIV.

Effect of shading by the

Effect of shading on

Annual space heating energy demand Annual sensible cooling energy demand
A $(\%)$

$+23$

$-36$
Typology

$\mathrm{B}(\%)$

$+14$

$-19$
$\mathrm{C}(\%)$

$+12$

$-11$ urban environment on the thermal energy demand

$1,653 \mathrm{kWh} / \mathrm{m}^{2}$, depending on location, see Tables XVI-XVIII, column I). Coherently the single-family home typology (type $\mathrm{C}$ ) has the highest TAEP (87 to $165 \mathrm{kWh} / \mathrm{m}^{2}{ }_{\mathrm{UFA}} \mathrm{a}$, depending on location) and the high-rise typology (type A) the lowest (9 to $17.1 \mathrm{kWh} / \mathrm{m}^{2}{ }_{\mathrm{UFA}} \mathrm{a}$, depending on location). For detailed results see Tables XVI-XVIII, right column. 
SASBE $7,3 / 4$

\section{2}

\section{External electrical energy demand}

Type $\mathrm{C}$ is the only of the investigated typologies that has the potential to reach a net-zero energy standard in all investigated locations. The highest potential lies in Athens, where thermal energy demand is the lowest and incident solar radiation is the highest $\left(-112.6 \mathrm{kWh} / \mathrm{m}^{2}{ }_{\text {UFA }} \mathrm{a}\right)$, the lowest potential lies in Helsinki, where thermal energy demand is the highest and incident solar radiation is the lowest $\left(-13.6 \mathrm{kWh} / \mathrm{m}^{2} \mathrm{UFA}^{\mathrm{a}} \mathrm{a}\right)$. The investigated high density typologies do not reach net-zero energy standards under the given boundary conditions (see Figure 17 and Table XIX).

\section{Discussion}

The results show, that at the four locations studied, the choice of typology matters most in Helsinki, where the energy demand of the single-family home typology is nearly 40 per cent higher than in the best apartment building typology and least in Vienna, where it is less than 20 per cent higher. If the specific UFA per person in the single-family home is higher than that in the apartment building typologies, as is often the case in reality, these differences will be more pronounced. This can be explained by the low winter-temperatures in Helsinki and the high surface-to-volume ratio of single-family homes, which leads to high transmission heat losses.

Table XV.

Embodied energy (EE) and annual embodied energy (AEE) demand per $\mathrm{m}^{2}$ of photovoltaic panel area for solar power systems

\begin{tabular}{|c|c|c|c|c|c|c|c|}
\hline \multirow[b]{2}{*}{ Building element } & \multicolumn{2}{|c|}{$\mathrm{EE}\left(\mathrm{MJ} / \mathrm{m}^{2}\right)$} & \multicolumn{2}{|c|}{ Lifespan } & \multicolumn{2}{|c|}{ AEE } & \multirow[b]{2}{*}{ Data source } \\
\hline & Constr. & Disp. & Total & (a) & $\left(\mathrm{MJ} / \mathrm{m}^{2}\right)$ & $\left(\mathrm{kWh} / \mathrm{m}^{2} \bullet \mathrm{a}\right)$ & \\
\hline Solar power system & 2,800 & 0 & 2,800 & 30 & 93 & 26 & SIA 2032 \\
\hline \multicolumn{8}{|c|}{ Source: SIA, 2010, 2013} \\
\hline
\end{tabular}

\begin{tabular}{|c|c|c|c|c|c|c|c|c|c|}
\hline Location & Surface & $\begin{array}{c}\mathrm{A} \\
\left(m^{2}\right) \\
\end{array}$ & $\begin{array}{l}\mathrm{AF} \\
(-)\end{array}$ & $\begin{array}{l}\mathrm{PV} \\
\left(m^{2}\right) \\
\end{array}$ & $\begin{array}{c}\mathrm{I} \\
\left(\mathrm{kWh} / \mathrm{m}^{2} \mathrm{a}\right)\end{array}$ & $\begin{array}{c}\eta \\
(-) \\
\end{array}$ & $\begin{array}{c}\mathrm{PP} \\
(\mathrm{kWh} / \mathrm{a})\end{array}$ & $\begin{array}{c}\mathrm{AEE} \\
(\mathrm{kWh} / \mathrm{a})\end{array}$ & $\begin{array}{c}\text { TAEP } \\
\left(\mathrm{kWh} / \mathrm{m}^{2}{ }_{U F A} \bullet a\right) \\
\end{array}$ \\
\hline \multicolumn{10}{|c|}{ Typology A } \\
\hline \multirow[t]{4}{*}{ Helsinki } & Facade SW & 3,185 & 0.30 & 956 & 501 & 0.15 & 71,806 & 24,843 & 2.1 \\
\hline & Facade SE & 3,185 & 0.30 & 956 & 487 & 0.15 & 69,799 & 24,843 & 2.0 \\
\hline & Roof & 1,250 & 0.75 & 938 & 942 & 0.15 & 132,469 & 24,375 & 4.8 \\
\hline & Total & 7,620 & & 2,849 & & & 274,074 & 74,061 & 9.0 \\
\hline \multirow[t]{4}{*}{ Dublin } & Facade SW & 3,185 & 0.30 & 956 & 467 & 0.15 & 66,933 & 24,843 & 1.9 \\
\hline & Facade SE & 3,185 & 0.30 & 956 & 448 & 0.15 & 64,210 & 24,843 & 1.8 \\
\hline & Roof & 1,250 & 0.75 & 938 & 940 & 0.15 & 132,188 & 24,375 & 4.8 \\
\hline & Total & 7,620 & & 2,849 & & & 263,330 & 74,061 & 8.5 \\
\hline \multirow[t]{4}{*}{ Vienna } & Facade SW & 3,185 & 0.30 & 956 & 559 & 0.15 & 80,119 & 24,843 & 2.5 \\
\hline & Facade SE & 3,185 & 0.30 & 956 & 565 & 0.15 & 80,979 & 24,843 & 2.5 \\
\hline & Roof & 1,250 & 0.75 & 938 & 1,127 & 0.15 & 158,484 & 24,375 & 6.0 \\
\hline & Total & 7,620 & & 2,849 & & & 319,582 & 74,061 & 11.0 \\
\hline \multirow[t]{4}{*}{ Athens } & Facade SW & 3,185 & 0.30 & 956 & 773 & 0.15 & 110,790 & 24,843 & 3.9 \\
\hline & Facade SE & 3,185 & 0.30 & 956 & 782 & 0.15 & 112,080 & 24,843 & 3.9 \\
\hline & Roof & 1,250 & 0.75 & 938 & 1,653 & 0.15 & 232,453 & 24,375 & 9.3 \\
\hline & Total & 7,620 & & 2,849 & & & 455,324 & 74,061 & 17.1 \\
\hline \multicolumn{10}{|c|}{$\begin{array}{l}\text { Notes: The area of photovoltaic panels (PV) is the product of the surface area (SA) of the considered building } \\
\text { surface and the area factor (AF). The annual production potential (PP) is the product of the annual solar } \\
\text { irradiation (I) and the efficiency factor }(\eta) \text {. The total annual energy production (TAEP) is the annual } \\
\text { production potential (PP) minus the annual embodied energy (AEE) divided by the usable floor area (UFA) of } \\
\text { the building. Italic values represent the total TAEP of all investigated building surfaces and are factored into } \\
\text { the calculation of the EEED (see Table XIX) }\end{array}$} \\
\hline
\end{tabular}

\section{Table XVI.}

Estimated annual production potential (PP), annual embodied energy (AEE) and total annual energy production (TAEP) of a solar power system with an efficiency of $\eta=0.15$ for typology $\mathrm{A}$ in different climatic contexts 


\begin{tabular}{|c|c|c|c|c|c|c|c|c|c|c|}
\hline$\underline{\text { Location }}$ & Surface & $\begin{array}{c}\text { A } \\
\left(\mathrm{m}^{2}\right) \\
\end{array}$ & $\begin{array}{l}\mathrm{AF} \\
(-) \\
\end{array}$ & $\begin{array}{l}\mathrm{PV} \\
\left(\mathrm{m}^{2}\right)\end{array}$ & $\begin{array}{c}\mathrm{I} \\
\left(\mathrm{kWh} / \mathrm{m}^{2} \mathrm{a}\right) \\
\end{array}$ & $\begin{array}{l}\eta \\
(-) \\
\end{array}$ & $\begin{array}{c}\mathrm{PP} \\
(\mathrm{kWh} / \mathrm{a})\end{array}$ & $\begin{array}{c}\mathrm{AEE} \\
(\mathrm{kWh} / \mathrm{a}) \\
\end{array}$ & $\begin{array}{c}\text { TAEP } \\
\left(\mathrm{kWh} / \mathrm{m}^{2}{ }_{\text {UFA }} \bullet \mathrm{a}\right) \\
\end{array}$ & building \\
\hline \multicolumn{10}{|c|}{ Typology B } & \\
\hline \multirow[t]{4}{*}{ Helsinki } & Facade SW & 4,165 & 0.30 & 1,250 & 551 & 0.15 & 103,271 & 32,487 & 2.6 & \\
\hline & & 4,165 & 30 & 1250 & 528 & 015 & 98,960 & 32,487 & 25 & \\
\hline & Roof & 5,100 & 0.75 & 3,825 & 942 & 0.15 & 540,473 & 99,450 & 16.3 & \\
\hline & Total & 13,430 & & 6,324 & & & 742,704 & 164,424 & 21.3 & \\
\hline \multirow[t]{4}{*}{ Dublin } & Facade SW & 4,165 & 0.30 & 1,250 & 518 & 0.15 & 97,086 & 32,487 & 2.4 & \\
\hline & Facade & 4,165 & 0.30 & 1,250 & 489 & 0.15 & 91,651 & 32,487 & 2.2 & \\
\hline & & 5,100 & 0.75 & 3,825 & 940 & 0.15 & 539,325 & 99,450 & 16.2 & \\
\hline & $\mathrm{Tc}$ & 13,430 & & 6,324 & & & 728,062 & 164,424 & 20.8 & \\
\hline \multirow[t]{4}{*}{ Vienna } & $\mathrm{Fa}$ & 4,165 & 0.30 & 1,250 & 617 & 0.15 & 115,641 & 32 & 3.1 & \\
\hline & & 5 & 0.30 & 1,250 & 615 & 0.1 & 115 & 32 & 3.1 & \\
\hline & Roof & 5,100 & 0.75 & 3,825 & 1,127 & 0.15 & 646,616 & 99,450 & 20.2 & \\
\hline & Total & 13,430 & & 6,324 & & & 877,524 & 164,424 & 26.3 & Table $Y$ \\
\hline \multirow[t]{4}{*}{ Athens } & Facade SW & 4,165 & 0.30 & 1,250 & 850 & 0.15 & 159,311 & 32,487 & 4.7 & stimated a \\
\hline & Facade SE & 4,165 & 0.30 & 1,250 & 851 & 0.15 & 159,499 & 32,487 & 4.7 & \\
\hline & Roof & 5,100 & 0.75 & 3,825 & 1,653 & 0.15 & 948,409 & 99,450 & 31.3 & \\
\hline & Total & 13,430 & & 6,324 & & & $1,267,219$ & 164,424 & 40.6 & Wr \\
\hline \multicolumn{10}{|c|}{$\begin{array}{l}\text { Notes: The area of photovoltaic panels (PV) is the product of the surface area (SA) of the considered building } \\
\text { surface and the area factor (AF). The annual production potential (PP) is the product of the annual solar } \\
\text { irradiation (I) and the efficiency factor }(\eta) \text {. The total annual energy production (TAEP) is the annual } \\
\text { production potential (PP) minus the annual embodied energy (AEE) divided by the usable floor area (UFA) of } \\
\text { the building. Italic values represent the total TAEP of all investigated building surfaces and are factored into } \\
\text { the calculation of the EEED (see Table XIX) }\end{array}$} & $\begin{array}{r}\text { production (TAEP) of } \\
\text { a solar power system } \\
\text { with an efficiency of } \\
\eta=0.15 \text { for typology } \\
\mathrm{B} \text { in different climatic } \\
\text { contexts }\end{array}$ \\
\hline
\end{tabular}

\begin{tabular}{llrlrlllll}
\hline Location & Surface & $\left(\mathrm{m}^{2}\right)$ & $(-)$ & $\left(\mathrm{m}^{2}\right)$ & $\left(\mathrm{kWh} / \mathrm{m}^{2} \mathrm{a}\right)$ & $(-)$ & $(\mathrm{kWh} / \mathrm{a})$ & $(\mathrm{kWh} / \mathrm{a})$ & $\left(\mathrm{kWh} / \mathrm{m}^{2}\right.$ UFA $\bullet$ \\
\hline Typology C C & & & & & & & & \\
Helsinki & Facade S & 75 & 0.30 & 23 & 687 & 0.15 & 2,319 & 585 & 12.3 \\
& Facade E+W & 82 & 0.50 & 41 & 454 & 0.15 & 2,778 & $1,060.8$ & 12.2 \\
& Roof & 85 & 0.90 & 77 & 942 & 0.15 & 10,809 & 1,989 & 62.6 \\
& Total & 242 & & 140 & & & 15,907 & 3,635 & 87.0 \\
Dublin & Facade S & 75 & 0.30 & 23 & 631 & 0.15 & 2,130 & 585 & 11.0 \\
& Facade E+W & 82 & 0.50 & 41 & 453 & 0.15 & 2,772 & $1,060.8$ & 12.1 \\
& Roof & 85 & 0.90 & 77 & 940 & 0.15 & 10,787 & 1,989 & 62.4 \\
& Total & 242 & & 140 & & & 15,688 & 3,635 & 85.5 \\
Vienna & Facade S & 75 & 0.30 & 23 & 759 & 0.15 & 2,562 & 585 & 14.0 \\
& Facade E+W & 82 & 0.50 & 41 & 535 & 0.15 & 3,274 & $1,060.8$ & 15.7 \\
& Roof & 85 & 0.90 & 77 & 1,127 & 0.15 & 12,932 & 1,989 & 77.6 \\
& Total & 242 & & 140 & & & 18,768 & 3,635 & 107.3 \\
Athens & Facade S & 75 & 0.30 & 23 & 1,009 & 0.15 & 3,405 & 585 & 20.0 \\
& Facade E+W & 82 & 0.50 & 41 & 739 & 0.15 & 4,523 & $1,060.8$ & 24.6 \\
& Roof & 85 & 0.90 & 77 & 1,653 & 0.15 & 18,968 & 1,989 & 12.4 \\
& Total & 242 & & 140 & & & 26,896 & 3,635 & 165.0
\end{tabular}

Notes: The area of photovoltaic panels (PV) is the product of the surface area (SA) of the considered building surface and the area factor (AF). The annual production potential (PP) is the product of the annual solar irradiation (I) and the efficiency factor $(\eta)$. The total annual energy production (TAEP) is the annual production potential (PP) minus the annual embodied energy (AEE) divided by the usable floor area (UFA) of the building. Italic values represent the total TAEP of all investigated building surfaces and are factored into the calculation of the EEED (see Table XIX)

Table XVIII.

Estimated annual production potential (PP), annual embodied energy (AEE) and total annual energy production (TAEP) of a solar power system with an efficiency of $\eta=0.15$ for typology $\mathrm{C}$ in different climatic contexts 
SASBE $7,3 / 4$ ,

\begin{tabular}{|c|c|c|c|c|c|}
\hline \multirow[b]{2}{*}{ Location } & \multirow[b]{2}{*}{ Heating and cooling } & \multicolumn{2}{|c|}{ Demand $\quad\left(\mathrm{kWh} / \mathrm{m}^{2} \mathrm{UFA}^{\bullet} \cdot \mathrm{a}\right)$} & \multirow[b]{2}{*}{$\begin{array}{l}\text { Supply } \\
\text { TAEP }\end{array}$} & \multirow[b]{2}{*}{$\begin{array}{r}\text { Total } \\
\text { EEED }\end{array}$} \\
\hline & & $\begin{array}{l}\text { Demand } \\
\text { Others }\end{array}$ & Total & & \\
\hline \multicolumn{6}{|c|}{ Typology A } \\
\hline Helsinki & 20.5 & 45.0 & 65.5 & 9.0 & 56.6 \\
\hline Dublin & 6.7 & 45.0 & 51.7 & 8.5 & 43.2 \\
\hline Vienna & 10.6 & 45.0 & 55.6 & 11.0 & 44.6 \\
\hline Athens & 5.9 & 45.0 & 50.9 & 17.1 & 33.8 \\
\hline \multicolumn{6}{|c|}{ Typology B } \\
\hline Helsinki & 21.3 & 45.0 & 66.3 & 21.3 & 45.0 \\
\hline Dublin & 7.0 & 45.0 & 52.0 & 20.8 & 31.2 \\
\hline Vienna & 11.0 & 45.0 & 56.0 & 26.3 & 29.7 \\
\hline Athens & 5.7 & 45.0 & 50.7 & 40.6 & 10.1 \\
\hline \multicolumn{6}{|c|}{ Typology C } \\
\hline Helsinki & 28.4 & 45.0 & 73.4 & 87.0 & -13.6 \\
\hline Dublin & 8.3 & 45.0 & 53.3 & 85.5 & -32.2 \\
\hline Vienna & 12.7 & 45.0 & 57.7 & 107.3 & -49.6 \\
\hline Athens & 7.4 & 45.0 & 52.4 & 165.0 & -112.6 \\
\hline
\end{tabular}

At the same time, the investigated single-family home typology has the highest potential for building integrated energy production. This is most pronounced in low latitudes, where the overall solar potential is higher. This can be explained be the fact that the high surface-tovolume ratio of the single-family dwelling allows to install more photovoltaics on the building envelope and the lower building densities lead to less mutual shading (see Table XIV).

These results show interesting implications regarding the choice of typology for the goal of achieving zero-energy buildings, as even if the thermal energy demand could be reduced to zero, the apartment building typologies in the sort of urban context outlined above would seem to have difficulty achieving this goal in many European climate zones, as long as energy consumption for household appliances is not reduced drastically (see Table XIX).

Seen from an urban perspective, the results suggest that net-zero energy urban areas could reach significantly higher densities in low latitudes with correspondingly high solar radiation levels than in higher latitudes: A net-zero urban area consisting of the three investigated building typologies would require an increasing proportion of single-family homes (type C) with increasing latitude in order to reach a net-zero energy balance. In the climate of Helsinki, the highest reachable density with a balanced share of energy demand and energy production would be 65 dwellings per hectare, while in the climate of Athens it would be 216 dwellings per hectare (see Figure 18 and Table XX). Taking into consideration that the roof area has the highest potential for building integrated energy production (see Tables XVI-XVIII), low-rise typologies with high densities seem particularly promising for net-zero energy developments and should be further investigated.

\section{Conclusions}

The following conclusions can be drawn from the work carried out in this study:

- The choice of building typology and corresponding urban density has a higher impact on the specific energy demand based on UFA in cold climate conditions (Helsinki) than in warm and moderate climate conditions.

- The choice of building typology and corresponding urban density has a higher impact on the potential for integrated renewable energy production in locations at lower latitudes. 


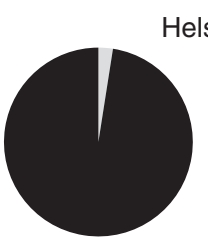

63 (dw/ha)

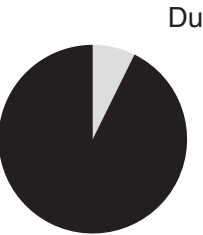

85 (dw/ha)

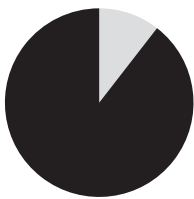

99 (dw/ha)

Athens

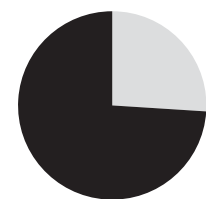

167 (dw/ha)

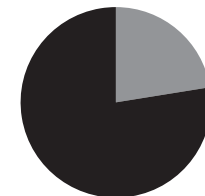

108 (dw/ha)

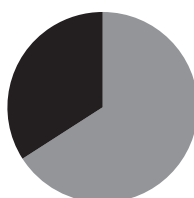

$216(\mathrm{dw} / \mathrm{ha})$

Type A - Type C * Type B - Type C

Note: The values under the pie charts represent the achieved densities in dwellings per hectare (dw/ha), based on $90 \mathrm{~m}^{2}$ UFA per dwelling
Residential

building typologies
Figure 18.

Required typology mix to achieve a NetZero-Energy district, based on a total site area of 100 ha.

- The investigated apartment buildings have a lower operational energy demand than the single-family homes at all locations. In cold climate conditions (Helsinki) this advantage is most pronounced.

- The investigated single-family home typology has the highest potential for building-integrated energy production at all locations. In low latitudes (Athens) this advantage is most pronounced.

- The combination of these results means that net-zero-energy developments can reach higher densities in warmer, sunnier climates than in colder climates with lower incident solar radiation.

\section{Outlook}

To fully understand the impact of building typology and corresponding urban morphology on the energy demand of a city, further studies are required. Other uses besides residential use, such as offices, services, public buildings or industry as well as a mix of 
SASBE $7,3 / 4$

Table XX. Typology mixes to reach a net-zero external electrical energy demand (EEED) for all investigated locations

\begin{tabular}{|c|c|c|c|c|c|c|c|}
\hline & $\begin{array}{l}\text { SA } \\
\text { (ha) }\end{array}$ & $\begin{array}{l}\text { TFA total } \\
\left(\mathrm{m}^{2}\right)\end{array}$ & $\begin{array}{l}\text { UFA total } \\
\left(\mathrm{m}^{2}\right)\end{array}$ & $\begin{array}{c}\text { EEED total } \\
(\mathrm{kWh} / \mathrm{a})\end{array}$ & $\begin{array}{c}\text { Dwellings } \\
(-)\end{array}$ & $\begin{array}{l}\mathrm{dw} / \mathrm{ha} \\
\left(\mathrm{ha}^{-1}\right)\end{array}$ & $\begin{array}{c}\text { FAR } \\
(-)\end{array}$ \\
\hline \multicolumn{8}{|l|}{ Helsinki } \\
\hline Type A & 2.5 & 157,348 & 110,143 & $6,234,109$ & 1,224 & 495 & 6.4 \\
\hline Type C & 97.5 & 552,669 & 458,390 & $-6,234,109$ & 5,093 & 52 & 0.6 \\
\hline Total & 100 & 710,017 & 568,534 & 0 & 6,317 & 63 & 0.7 \\
\hline Type B & 5.0 & 177,603 & 134,978 & $6,074,007$ & 1,500 & 301 & 3.6 \\
\hline Type C & 95.0 & 538,476 & 446,618 & $-6,074,007$ & 4,962 & 52 & 0.6 \\
\hline Total & 100 & 716,078 & 581,596 & 0 & 6,462 & 65 & 0.7 \\
\hline \multicolumn{8}{|l|}{ Dublin } \\
\hline Type A & 7.3 & 464,008 & 324,806 & $14,031,599$ & 3,609 & 495 & 6.4 \\
\hline Type C & 92.7 & 525,389 & 435,764 & $-14,031,599$ & 4,842 & 52 & 0.6 \\
\hline Total & 100 & 989,397 & 760,569 & 0 & 8,451 & 85 & 1.0 \\
\hline Type B & 15.2 & 541,443 & 411,497 & $12,838,705$ & 4,572 & 301 & 3.6 \\
\hline Type C & 84.8 & 480,723 & 398,718 & $-12,838,705$ & 4,430 & 52 & 0.6 \\
\hline Total & 100 & $1,022,167$ & 810,214 & 0 & 9,002 & 90 & 1.0 \\
\hline \multicolumn{8}{|l|}{ Vienna } \\
\hline Type A & 10.5 & 668,355 & 467,849 & $20,866,051$ & 5,198 & 495 & 6.4 \\
\hline Type C & 89.5 & 507,211 & 420,687 & $-20,866,051$ & 4,674 & 52 & 0.6 \\
\hline Total & 100 & $1,175,566$ & 888,535 & 0 & 9,873 & 99 & 1.2 \\
\hline Type B & 22.4 & 801,045 & 608,794 & $18,081,196$ & 6,764 & 301 & 3.6 \\
\hline Type C & 77.6 & 439,517 & 364,540 & $-18,081,196$ & 4,050 & 52 & 0.6 \\
\hline Total & 100 & $1,240,562$ & 973,335 & 0 & 10,815 & 108 & 1.2 \\
\hline \multicolumn{8}{|l|}{ Athens } \\
\hline Type A & 26.0 & $1,655,468$ & $1,158,827$ & $39,168,364$ & 12,876 & 495 & 6.4 \\
\hline Type C & 74.0 & 419,398 & 347,854 & $-39,168,364$ & 3,865 & 52 & 0.6 \\
\hline Total & 100 & $2,074,866$ & $1,506,681$ & 0 & 16,741 & 167 & 2.1 \\
\hline Type B & 65.9 & $2,352,080$ & $1,787,580$ & $18,054,562$ & 19,862 & 301 & 3.6 \\
\hline Type C & 34.1 & 193,321 & 160,342 & $-18,054,562$ & 1,782 & 52 & 0.6 \\
\hline Total & 100 & $2,545,400$ & $1,947,923$ & 0 & 21,644 & 216 & 2.5 \\
\hline
\end{tabular}

Notes: The table shows the necessary site area (SA), and corresponding total floor area (TFA total), usable floor area (UFA total) and number of dwellings (at $90 \mathrm{~m}^{2}$ UFA per dwelling) per building type and the resulting densities in dwellings per hectare (dw/ha) and floor area ratio (FAR). Italic values represent the resulting densities, based on a site are of 1 hectare, as shown in Figure 18

uses should be investigated to represent a wider spectrum of urban functions. More typologies should be investigated, particularly low-rise typologies seem to be particularly promising for net-zero energy developments.

In order to assess the total energy performance of various urban morphologies, the embodied energy[8] of the various building typologies, as well as embodied and operational energy demand for transport and infrastructure would also need to be considered in further studies.

Other issues such as the effect of the various typologies on the urban heat island effect are interesting areas for further research. Sensibility analyses should be carried out to better understand the impact of different parameters, such as user behaviour, insulation level, or climate change on the total energy performance.

\section{Glossary}

a

A

AEE
Annum (year)

Area

Annual embodied energy 


\begin{tabular}{|c|c|c|}
\hline $\mathrm{AF}$ & Area factor & Residential \\
\hline $\mathrm{PP}$ & Annual production potential & building \\
\hline BIPV & Building integrated photovoltaics & Dumuing \\
\hline $\mathrm{COP}$ & Coefficient of performance & \\
\hline DHWS & Domestic hot water services & \\
\hline dw/ha & Dwellings per hectare & \\
\hline $\mathrm{E}$ & East & \\
\hline $\mathrm{EE}$ & Embodied energy & 248 \\
\hline EEED & External electrical energy demand & \\
\hline FAR & Floor area ratio & \\
\hline ha & Hectare & \\
\hline HVAC & Heating, ventilating, and air conditioning & \\
\hline kWh & Kilowatt hour(s) & \\
\hline $\mathrm{kWh} / \mathrm{m}^{2} \mathrm{UFA}^{\mathrm{a}}$ & Kilowatt hours per $\mathrm{m}^{2}$ UFA and year & \\
\hline MEP & Mechanical, electrical, and plumbing & \\
\hline $\mathrm{N}$ & North & \\
\hline PV & Photovoltaics & \\
\hline S & South & \\
\hline SA & Site area & \\
\hline SE & South East & \\
\hline surf. & Surface & \\
\hline SW & South West & \\
\hline TAEP & Total annual energy production & \\
\hline TFA & Total floor area & \\
\hline UFA & Usable floor area & \\
\hline W & West & \\
\hline$\eta$ & Efficiency factor (output power/input power) & \\
\hline$\lambda$ & Thermal conductivity $(\mathrm{W} /(\mathrm{mK}))$ & \\
\hline constr. & construction & \\
\hline disp. & disposal & \\
\hline$I$ & annual solar irradiation $\left(\mathrm{kWh} /\left(\mathrm{m}^{2} \mathrm{a}\right)\right)$ & \\
\hline $\mathrm{kWh} / \mathrm{a}$ & kilowatt hours per year & \\
\hline $\mathrm{kWh} / \mathrm{m}^{2} \mathrm{a}$ & kilowatt hours per $\mathrm{m}^{2}$ year & \\
\hline$K$ & Kelvin & \\
\hline$m$ & metre(s) & \\
\hline$m^{2}$ & square metre(s) & \\
\hline $\mathrm{p} / \mathrm{ha}$ & persons per hectare & \\
\hline MJ & megajoule & \\
\hline $\mathrm{NE}$ & north-east & \\
\hline NW & north-west & \\
\hline SHGC & solar heat gain coefficient (transmitted solar energy/incident solar energy) & \\
\hline$U$-value & overall heat transfer coefficient $\left(\mathrm{W} /\left(\mathrm{m}^{2} \mathrm{~K}\right)\right)$ & \\
\hline
\end{tabular}

\section{Notes}

1. Primary energy is defined as the energy that has not been subjected to any conversion or transformation process.

2. Final energy is the energy supplied to the end user.

3. See: http://webtool.building-typology.eu/\#bm

4. See: www.entranze.enerdata.eu/ 
SASBE

$7,3 / 4$

248

5. For the purposes of this study, thermal energy is defined as the energy, required for heating and cooling of conditioned rooms, excluding hot water production. It represents the demand, that has to be covered by heating and cooling systems and does not include conversion and system distribution losses.

6. See: www.iesve.com/software/software-validation

7. The annual embodied energy demand is defined as the embodied energy of a product, divided by its life expectancy (in years).

8. Embodied energy is defined as the energy consumed by all the processes required to manufacture and deliver a product to site, as well as the energy required for its disposal at the end of its useful life.

\section{References}

Austrian Institute of Construction Engineering (OIB) (2015), "OIB guideline 2.3 - safety in case of fire in buildings with a fire escape level in excess of $22 \mathrm{~m}$ ", available at: www.oib.or.at/sites/default/ files/richtlinie_2.3_26.03.15.pdf (accessed 26 July 2017).

Belden Russonello and Stewart LLC (2011), "The 2011 community preference survey - what Americans are looking for when deciding where to live [analysis of a survey of 2071 American adults nationally conducted for the national association of realtors]", available at: www. stablecommunities.org/sites/all/files/library/1608/smartgrowthcommsurveyresults2011.pdf (accessed 26 July 2017).

Brownstone, D. and Golob, T. (2009), "The impact of residential density on vehicle usage and energy consumption”, Journal of Urban Economics, Vol. 65 No. 1, pp. 91-98, doi: 10.1016/j.jue.2008.09.002.

Buildings Performance Institute Europe (BPIE) (Ed.) (2011), "Europe's buildings under the microscope: a country-by-country review of the energy performance of buildings", available at: http://bpie.eu/wpcontent/uploads/2015/10/HR_EU_B_under_microscope_study.pdf (accessed 25 September 2017).

Cali, D., Osterhage, T., Streblow, R. and Müller, D. (2016), "Energy performance gap in refurbished German dwellings: lesson learned from a field test", Energy and Buildings, Vol. 127, pp. 1146-1158, doi: 10.1016/j.enbuild.2016.05.020.

Cody, B. and Loeschnig, W. (2011), "Urban Density and Energy”, TU Graz Research, Vol. 6, pp. 13-16, available at: www.tugraz.at/fileadmin/user_upload/tugrazInternal/News_Stories/Print/ research/pdf/research_6_2011.pdf (accessed 26 July 2017).

Compagnon, R. (2004), "Solar and daylight availability in the urban fabric", Energy and Buildings, Vol. 36 No. 4, pp. 321-328, doi: 10.1016/j.enbuild.2004.01.009.

Elsland, R., Peksen, I. and Wietschel, M. (2014), "Are internal heat gains underestimated in thermal performance evaluation of buildings?”, Energy Procedia, Vol. 62, pp. 32-41, doi: 10.1016/j. egypro.2014.12.364.

Ewing, R. and Cervero, R. (2010), "Travel and the built environment", Journal of the American Planning Association, Vol. 76 No. 3, pp. 265-294, doi: 10.1080/01944361003766766.

Karjalainen, S. (2016), "Should we design buildings that are less sensitive to occupant behaviour? A simulation study of effects of behaviour and design on office energy consumption", Energy Efficiency, Vol. 9 No. 6, pp. 1257-1270, doi: 10.1007/s12053-015-9422-7.

Loeschnig, W. (2012), "Finite Dense”, in Graz University of Technology (Eds), Graz Architecture Magazine, Vol. 8, Springer, Vienna, pp. 142-151.

Loga, T., Stein, B. and Diefenbach, N. (2016), "TABULA building typologies in 20 European countries - making energy-related features of residential building stocks comparable”, Energy and Buildings, Vol. 132, pp. 4-12, doi: 10.1016/j.enbuild.2016.06.094.

Martinaitis, V., Zavadskas, E.K., Motuzienė, V. and Vilutienè, T. (2015), "Importance of occupancy information when simulating energy demand of energy efficient house: a case study", Energy and Buildings, Vol. 101, pp. 64-75, doi: 10.1016/j.enbuild.2015.04.031.

Newton, P., Tucker, S. and Ambrose, M. (2000), "Housing form, energy use and greenhouse gas emissions", in Williams, K., Burton, E. and Jens, M. (Eds), Achieving Sustainable Urban Form, Spon Press, London, pp. 74-83. 
Nguyen, T.A. and Aiello, M. (2013), "Energy intelligent buildings based on user activity: a survey", Energy and Buildings, Vol. 56, pp. 244-257, doi: 10.1016/j.enbuild.2012.09.005.

Nichols, B. and Kockelman, K. (2014), "Life-cycle energy implications of different residential settings recognizing buildings, travel, and public infrastructure", Energy Policy, Vol. 68, pp. 232-242, doi: 10.1016/j.enpol.2013.12.062.

Norman, J., MacLean, H. and Kennedy, C. (2006), "Comparing high and low residential density - lifecycle analysis of energy use and greenhouse gas emissions", Journal of Urban Planning and Development, Vol. 132 No. 1, pp. 10-21, doi: 10.1061/(asce)0733-9488(2006)132:1(10).

Residential building typologies

Oikonomou, M. (2014), "The transformation of the urban block in the European city", in Oliveira, V., Pinho, P., Batista, L., Patatas, T. and Monteiro, C. (Eds), Our Common Future in Urban Morphology, FEUP, Porto, pp. 484-497, available at: http://isuf2014.fe.up.pt/ISUF2014\%20ebook.pdf (accessed 26 July 2017).

Puurunen, E. and Organschi, A. (2013), "Multiplier effect: high performance construction assembles and urban density in US housing", in Khare, A. and Beckman, T. (Eds), Mitigating Climate Change - The Emerging Face of Modern Cities, Springer, Heidelberg, pp. 183-206.

Schakib-Ekbatan, K., Çakıcı, F.Z., Schweiker, M. and Wagner, A. (2015), "Does the occupant behaviour match the energy concept of the building? - analysis of a German naturally ventilated office building”, Energy and Buildings, Vol. 84, pp. 142-150, doi: 10.1016/j.buildenv.2014.10.018.

Statistics Austria (2009), "Gebäude- und Wohnungsregister", available at: http://statcube.at (accessed 26 July 2017).

Statistics Austria (2017a), "Housing conditions (main residences) by provinces (time series)", available at: www.statistik.at/web_en/statistics/PeopleSociety/housing/housing_conditions/079266.html (accessed 26 July 2017).

Statistics Austria (2017b), "Size of dwellings (main residences) by provinces (time series)", available at: www.statistik.at/web_en/statistics/PeopleSociety/housing/housing_conditions/081236.html (accessed 26 July 2017).

Steemers, K. (2003), "Energy and the city: density, buildings and transport", Energy and Buildings, Vol. 35 No. 1, pp. 3-14, doi: 10.1016/s0378-7788(02)00075-0.

Stejskal, M., Bußwald, P., Ferk, H., Supper, S. and Tappeiner, G. (2011), "Bilanzierung der Grauen Energie in Wohnbau und zugehoeriger Infrastruktur-Erschliessung - Bericht zu Arbeitspaket AP2 des Projekts ZERsiedelt (Balancing of grey energy in housing and associated infrastructure development - Report on work package 2 of the research project ZERsiedelt)", available at: www.zersiedelt.at/zersiedelung-studien-oesterreich/AP2-zersiedelt-graue-energie-wohnbau.pdf (accessed 26 July 2017).

Swiss Society of Engineers and Architects (2010), Graue Energie von Gebaeuden [Grey Energy of Buildings], SIA, Zurich.

Swiss Society of Engineers and Architects (2013), "Graue energie von Gebaeuden: Korrigenda C1 zu SIA 2032:2010 (grey energy of buildings: corrigenda C1 to SIA 2032:2010), SIA, Zurich", available at: http://shop.sia.ch/8d7e837c-2888-4e04-b628-f36edbd1d39c/D/DownloadAnhang (accessed 26 July 2017).

Tereci, A., Ozkan, S. and Eicker, U. (2013), "Energy benchmarking for residential buildings", Energy and Buildings, Vol. 60, pp. 92-99, doi: 10.1016/j.enbuild.2012.12.004.

Uerge-Vorsatz, D., Eyre, N., Graham, P., Harvey, D., Hertwich, E., Jiang, Y., Kornevall, C., Majumdar, M., McMahon, J., Mirasgedis, S., Murakami, S. and Novikova, A. (2012), "Energy end-use: buildings", in Global Energy Assessment (GEA) (Ed.), Global Energy Assessment: Toward a Sustainable Future, Cambridge University Press, Cambridge, New York, NY, pp. 649-760.

Zellmann, P. and Mayrhofer, S. (2013), "Wohnsituation und Wohnwuensche - Ein eigenes Haus als Wunsch, aber auch fuer viele Wirklichkeit" (Housing Situation and Desires - An own House as a Desire, but also the Reality for Many), ift Forschungstelegramm, p. 4, available at: www. freizeitforschung.at/data/forschungsarchiv/2013/115.\%20FT\%204-2013_Wohnsituation.pdf (accessed 26 July 2017). 
SASBE

$7,3 / 4$

\section{Further reading}

Chen, S., Yang, W., Yoshino, H., Levine, M., Newhouse, K. and Hinge, A. (2015), "Definition of occupant behaviour in residential buildings and its application to behaviour analysis in case studies", Energy and Buildings, Vol. 104, pp. 1-13, doi: 10.1016/j.enbuild.2015.06.075.

\section{About the authors}

Professor Brian Cody is Chartered Engineer specializing in the analysis and design of energy efficient cities, buildings and systems. He is Professor and Director of the Institute of Buildings and Energy at Graz University of Technology since 2004, where his focus in research and teaching is on maximising the energy efficiency of buildings and cities and Visiting Professor at the University of Applied Arts in Vienna since 2005. He is the Founder and Principal of the consultancy Energy Design Cody, founded in 2010. Before his appointment as professor in Graz he was an Associate Director, Business Development Leader and Design Leader at ARUP and lectured at Leibniz University in Hannover.

Wolfgang Loeschnig is Freelance Architect and a Lecturer at the Institute of Buildings and Energy, Graz University of Technology, since 2014. He is the Founder and Principal of the architecture office Universaldesign, founded in 2013, and is currently working on his $\mathrm{PhD}$ thesis on urban density and energy efficiency.

Alexander Eberl is University Assistant at the Institute of Buildings and Energy, Graz University of Technology, since 2014. He holds a Master's Degree in Architecture and is currently working on his $\mathrm{PhD}$ thesis on the revitalisation of buildings of the era of Structuralism. Alexander Eberl is the corresponding author and can be contacted at: alexander.eberl@tugraz.at

For instructions on how to order reprints of this article, please visit our website: 